Uniwersytet Przyrodniczo-

Humanistyczny w Siedlcach

Siedlce University of Natural

Sciences and Humanities

https://bazawiedzy.uph.edu.pl

\begin{tabular}{|l|l|}
\hline Publikacja / Publication & $\begin{array}{l}\text { DNA methylation analysis of the gene CDKN2B in Gallus gallus (chicken), } \\
\text { Gryzińska Magdalena, Andraszek Katarzyna, Jocek Grzegorz }\end{array}$ \\
\hline $\begin{array}{l}\text { Adres publikacji w Repozytorium URL } \\
\text { / Publication address in Repository }\end{array}$ & https://bazawiedzy.uph.edu.pl/info/article/UPH57a62febea5542c9bc4bdc9be775f5da/ \\
\hline $\begin{array}{l}\text { Data opublikowania w Repozytorium / } \\
\text { Deposited in Repository on }\end{array}$ & 22 paź 2021 \\
\hline Rodzaj licencji / Type of licence & Other open licence O \\
\hline Cytuj tę wersję / Cite this version & $\begin{array}{l}\text { Gryzińska Magdalena, Andraszek Katarzyna, Jocek Grzegorz: DNA methylation } \\
\text { analysis of the gene CDKN2B in Gallus gallus (chicken), Folia Biologica-Krakow, } \\
\text { vol. 61, no. 3, 2013, pp. 165-171 }\end{array}$ \\
\hline
\end{tabular}




\title{
DNA Methylation Analysis of the Gene CDKN2B in Gallus gallus (Chicken)
}

\author{
Magdalena GRYZIŃSKA，Katarzyna ANDRASZEK and Grzegorz JOCEK
}

Accepted May 15, 2013

\begin{abstract}
GRYZIŃSKA M., ANDRASZEK K., G. JOCEK. 2013. DNA methylation analysis of the gene CDKN2B in Gallus gallus (chicken). Folia Biologica (Kraków) 61: 165-171.

Methylation is an epigenetic modification of DNA affecting gene expression without changing the structure of nucleotides. It plays a crucial role in the embryonic and post-embryonic development of living organisms. Methylation level is tissue and species-specific and changes with age. The study was aimed at identifying the methylation of the CDKN2B gene situated at locus bar in Polbar chickens on the $6^{\text {th }}$ and $18^{\text {th }}$ day of embryonic development using the MSP (methylation-specific PCR) method. Methylation was not detected in the promoter region of gene $C D K N 2 B$ on the $6^{\text {th }}$ and $18^{\text {th }}$ day of embryonic development. As one of the five genes responsible for melanine activity in melanocytes and highly active, it can contribute to the production of this pigment. The present research broadens the current
\end{abstract} knowledge of the chicken epigenome and the mechanism of autosexing in birds.

Key words: DNA methylation, epigenetics, MSP (methylation-specific PCR), Gallus gallus, Polbar, barred gene.

Magdalena GRYZIŃSKA, Grzegorz JOCEK, Department of Biological Basis of Animal Production, University of Life Sciences, Akademicka 13, 20-950 Lublin, Poland. Magdalena.gryzinska@up.lublin.pl

Katarzyna ANDRASZEK, Institute of Bioengineering and Animal Breeding, Siedlce University of Natural Sciences and Humanities, B. Prusa 14, 08-110 Siedlce, Poland. andrasz@uph.edu.pl

The notion of epigenetics includes mechanisms that affect genetic material expression without changing the fundamental sequence of nucleotides in a gene. These mechanisms are essential during the entire development of an organism, primarily in relation to ageing. The epigenome sets the pattern for all epigenetic modifications and is responsible for tissue- and organ-specific cell differentiation by means of selective gene repression and expression (JONES \& MARTIENSSEN 2005). The epigenome is dynamic and, unlike the genome, it is different between particular body tissues (EHRLICH 2003). A crucial role in the regulation of gene expression and repression, chromatin modelling and histone modification is played by DNA methylation (CHUANG \& JONES 2007; PŁACHETKA et al. 2010; GRUBER 2011).

DNA methylation is a biochemical process that controls chromatin structure. The incorporation of a methyl group into cytosine within $\mathrm{CpG}$ islands leads to changes in gene transcription activity and chromatin structure and conformation. The area marked with methyl groups is transformed into heterochromatin, and the expression of genes in this area becomes suppressed (REIK et al. 2001; Cleveland et al. 2003; OLSZEWSKA 2007).
Molecular biology methods make it possible to analyse the methylation of both the entire genome and particular genes. The basic differentiation is assessed on the basis of quantitative or qualitative 5-methylocytosine assaying (GRYZIŃSKA et al. 2013). The MSP (methylation-specific PCR) technique is a qualitative technique based on the reaction between sodium hydrogen sulphate and nucleic acid (HERMAN et al. 1996; COLLEMAN \& RIVENBARK 2006). As a result of the reaction, cytosine or 5 -methylocytosine is deaminated in single-strand DNA, and the modified DNA is used as a matrix in the MSP reaction (AZHIKINA \& SVERDLOV, 2005). DNA amplification is performed using two pairs of primers containing one or more $\mathrm{CpG}$ loci. The primers are designed to differentiate methylated and non-methylated bases. The first pair of primers detects 5-methylocytosine as cytosine. It is thus complementary and joins the unchanged DNA fragment. The other pair of primers is, on the other hand, complementary to the sequence in which 5methylocytosine has been transformed into thymine (GRYZIŃSKA et al. 2012). The advantages of this method include rapid analysis, the possibility to obtain results from small DNA amounts $(5 \mu \mathrm{g})$, specificity and sensitivity. Methylation can 
be detected even when just $0.1 \%$ of the alleles have been methylated (SULEWSKA et al. 2007).

Research on genome methylation or genespecific methylation has been undertaken chiefly in man to analyse neoplastic transformations. The literature increasingly more often provides results of studies concerning mammalian genome methylation. On the other hand, data relating to the methylation of the avian genome are infrequent. The use of Gallus domesticus for the present study was not arbitrary. Gallus domesticus is a model organism referred to in biomedical and evolutionary research, comparative genomics and epigenetic studies. The publication of the entire chicken genome sequence revealed the existence of synthenic regions between the human and avian genomes which show that despite 300 million years of divergence between mammals and birds, numerous DNA sequences have remained conservative. The genome of Gallus domesticus is the only mapped avian genome and is used as a model in comparative genomics for at least two reasons. First, the genome is relatively small, $1 / 3$ the size of the human genome, yet harbors orthologs to most of the genes in man (GREGORY 2002; ICGSC 2004; MASABANDA et al. 2004; RUBIN et al. 2010).

Polbar chickens are the only autosexing chicken breed in Poland and one of the few autosexing poultry breeds worldwide. The breed stems from the local Greenleg Partridge stock and the paternal Plymouth Rock component. The new breed was named "Polbar", since an indigenous Polish breed (-pol) was supplemented with the bar gene. The dominant allele (B) inhibits melanin deposition which causes white stripes to appear in the feathers of adult birds. The bar gene is located on the Z chromosome (KAUFMAN 1963; GRYZIŃSKA \& NIESPODZIEWAŃSKI 2009). Little Polbar cocks are light grey (occasionally with a touch of regular grey), while little hens are dark, with a black supercilium in the extended line from the eye (Fig. 1a). Only during the first couple of days following hatching is it possible to identify the sex of the chicks on the basis of differential plumage. Afterwards, the sex-specific colour of the down feathers of the little hens and cocks gradually fades away. Mature birds are striped with grey and yellow legs (Fig. 1b). (KAUFMAN 1963; GRYZIŃSKA et al. 2008a, 2008b; GRYZIŃSKA \& NIESPODZIEWAŃSKI 2009).

According to available reports, the bar locus contains five genes: micro-RNA 31 (miRNA-31), methylthioadenosine phosphorylase (MTAP), tripartite motif 36 (TRIM36), protein geranylgeranyltransferase type I, $\beta$ subunit $(P G G T 1 B)$ and (analysed in this study) gencyclin-dependent kinase inhibitor $2 \mathrm{~B}(C D K N 2 B)$. The bar locus genes

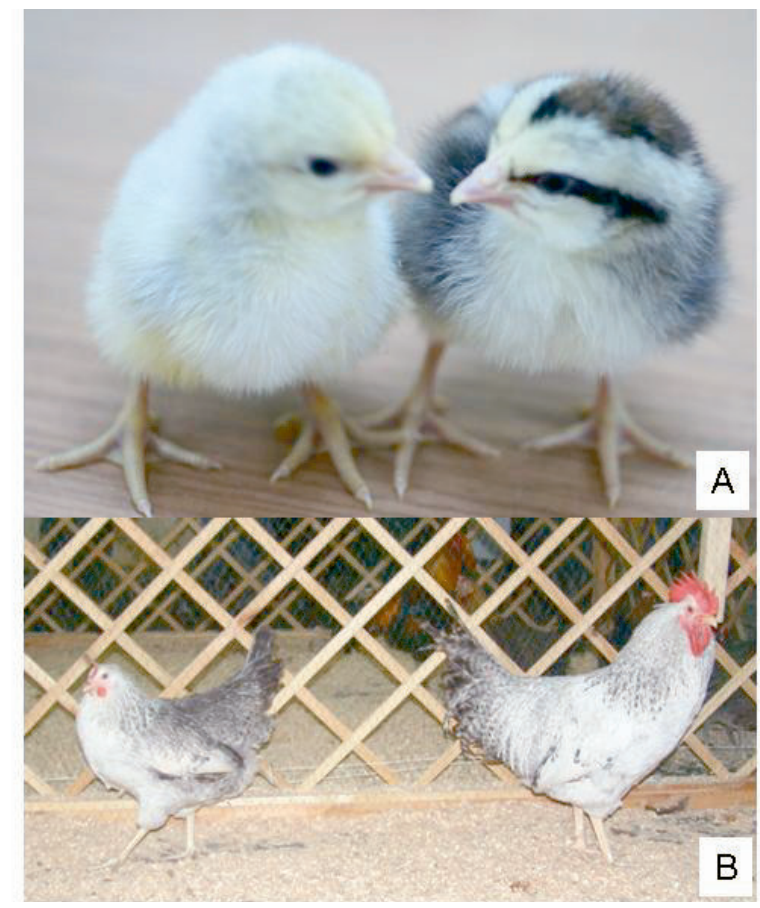

Fig. 1. Polbar chickens: chicks (a), mature birds (b).

are associated with melanine activity in melanocytes (DORSHORST \& ASHWELL 2009).

The $C D K N 2 B$ gene encodes proteins similar to one of the two cyclino-dependent kinase inhibitors present in mammals that control CDK4 and CDK6 kinase activity. In human creatinocytes these proteins are induced by TGF-beta cytokine which inhibits cellular growth in the G1 phase of the cellular cycle. Moreover, the $C D K N 2 A / B$ locus has a key role in cell cycle regulation. It encodes both the ARF protein, which binds the p53stabilizing protein MDM2, and the INK4 protein, a cyclin-dependent kinase inhibitor. Loss-of-function mutations in $C D K N 2 A$ are responsible for familiar forms of human melanoma (LIMA et al. 2008; HELLSTRÖM et al. 2010).

The study was aimed at identifying $C D K N 2 B$ methylation during embryonic development in Polbar chickens by means of the MSP (methylation-specific PCR) technique.

\section{Material and Methods}

\section{Animals}

The study involved Polbar autosexing chickens. At present, the only Polbar population worldwide is kept at the Felin Laura Kauffman Didactic and Research Station for Small Animals which belongs to the Department of Biological Basis of Animal Production of the University of Life Sciences in Lublin. The population includes 810 hens 
Table 1

Parameters of the primers for the PCR reaction

\begin{tabular}{|c|c|c|c|c|c|c|}
\hline No & Primer & Sequence $5^{\prime} \rightarrow 3^{\prime}$ & Size (bp) & $\mathrm{T}_{\mathrm{m}}(\mathrm{C})$ & $\mathrm{T}_{\mathrm{a}}(\mathrm{C})$ & $\% \mathrm{GC}$ \\
\hline $1 \mathrm{~A}$ & 1CDKN2B_MF & ATTTCGTCGTTTGAGAGTTGTC & 22 & 61.99 & \multirow{2}{*}{57} & 41 \\
\hline $1 \mathrm{~B}$ & 1CDKN2B_MR & CCGTACTAACCGCTCTCTACG & 21 & 62.59 & & 57 \\
\hline $2 \mathrm{~A}$ & 1CDKN2B_UF & TGTTGTTTGAGAGTTGTTGGG & 21 & 62.53 & \multirow{2}{*}{57} & 43 \\
\hline $2 \mathrm{~B}$ & 1CDKN2B_UR & ССАТАСТААССАСТСТСТАСАССА & 24 & 60.84 & & 46 \\
\hline
\end{tabular}

$\mathrm{T}_{\mathrm{a}}$ - matrix incorporation temperature; $\mathrm{T}_{\mathrm{m}}$ - melting temperature; $\mathrm{MF}$ - complementary primer for the leading strand at the methylation site; MR - complementary primer for the delayed strand at the methylation site; UF - complementary primer for the leading strand at the non-methylated site; UR - complementary primer for the delayed strand at the non-methylated site

and 80 cocks (GRYZIŃSKA \& NIESPODZIEWAŃSKI 2009).

The Polbar breed is covered by a gene pool protection program aimed at the preservation of populations, the maintenance of genetic variability, reduction of the gene share of foreign breeds, as well as the restoration and stabilisation of the phenotypic and genetic parameters of traits typical of local breeds (CALIK 2009; WÓJCIK et al. 2012).

\section{Sample preparation}

Female embryos collected on the sixth and eighteenth day of embryonic development comprised the experimental material (10 embryos for each age group). The material was collected in accordance with the $2^{\text {nd }}$ Lublin Local Ethical Commission for Animal Experiments Resolution (Resolution $8 / 11$ ) dated $15 / 03 / 2011$.

DNA was isolated from skin cells using a genomic DNA isolation kit (Genomic Midi AX from A\&A Biotechnology).

\section{MS PCR}

DNA conversion was performed by means of the EZ DNA Methylation-Gold Kit (D5001) from Zymo Research. The obtained eluate was the DNA intended for the PCR reaction. The MSP reaction was conducted in an MJ Research PTC-225 Peltier Thermal Cycler. The reaction primers were designed so that one pair binded at the methylation site, where methylocytosine remained a cytosine, and the other pair at the site where cytosine deaminated into uracil. Table 1 shows the primer sequences used for the PCR reaction.

Investigated gene $C D K N 2 B$ (cyclin-dependent kinase inhibitor 2B) ) [Gallus gallus (chicken)]. Gene ID: 395076, Location - chromosome Z; Locus NC_006127 (BELLOTT et al. 2010).

\section{Primers}

Primers for MSP were complementary to the gene promoter region. Criteria for the selection of primers: island size $>100$; GC percent $>50.0$; obs/exp 0.60 (Fig. 2).

PCR compromised a total reaction volume of $25 \mu \mathrm{l}$. A thermal cycler (MJ Research) was programmed for an initial incubation at $94^{\circ} \mathrm{C}$ for $3 \mathrm{~min}$; $35 \mathrm{cy}-$ cles each with denaturation at $94^{\circ} \mathrm{C}$ for $1 \mathrm{~min}$, annealing at $57^{\circ} \mathrm{C}$ for $1 \mathrm{~min}$, and extension at $72^{\circ} \mathrm{C}$ for $1 \mathrm{~min}$; and a final cycle at $72^{\circ} \mathrm{C}$ for $10 \mathrm{~min}$. Amplification products were size-separated by electrophoresis in $1.8 \%$ agarose gels and visualized by ultraviolet illumination after staining with ethidium bromide.

\section{PCR amplification products}

Methylation lenght (173 bp):

5'ATTTCGTCGTTTGAGAGTTGTCGGGGGT GCGGGTTTGGAGCGGCGGATACGCGCGT TTTTATGGGTTGGGTTTTTTTCGCGGGTC GGTAGTCGCGGGTAGCGAGAGGGGTTTC GTTGTTTATAGATACGAGGTCGGGTCGGG TCGGGTATGGCGTAGAGAGCGGTTAGTA CGG 3'

Non-methylation length (173 bp/176bp CCC from the 5 ' end)

5'CCCATTTTGTTGTTTGAGAGTTGTTGGG GGTGTGGGTTTGGAGTGGTGGATATGTGT GTTTTTATGGGTTGGGTTTTTTTTGTGGGT TGGTAGTTGTGGGTAGTGAGAGGGGTTTT GTTGTTTATAGATATGAGGTTGGGTTGGG TTGGGTATGGTGTAGAGAGTGGTTAGTAT GG 3' 


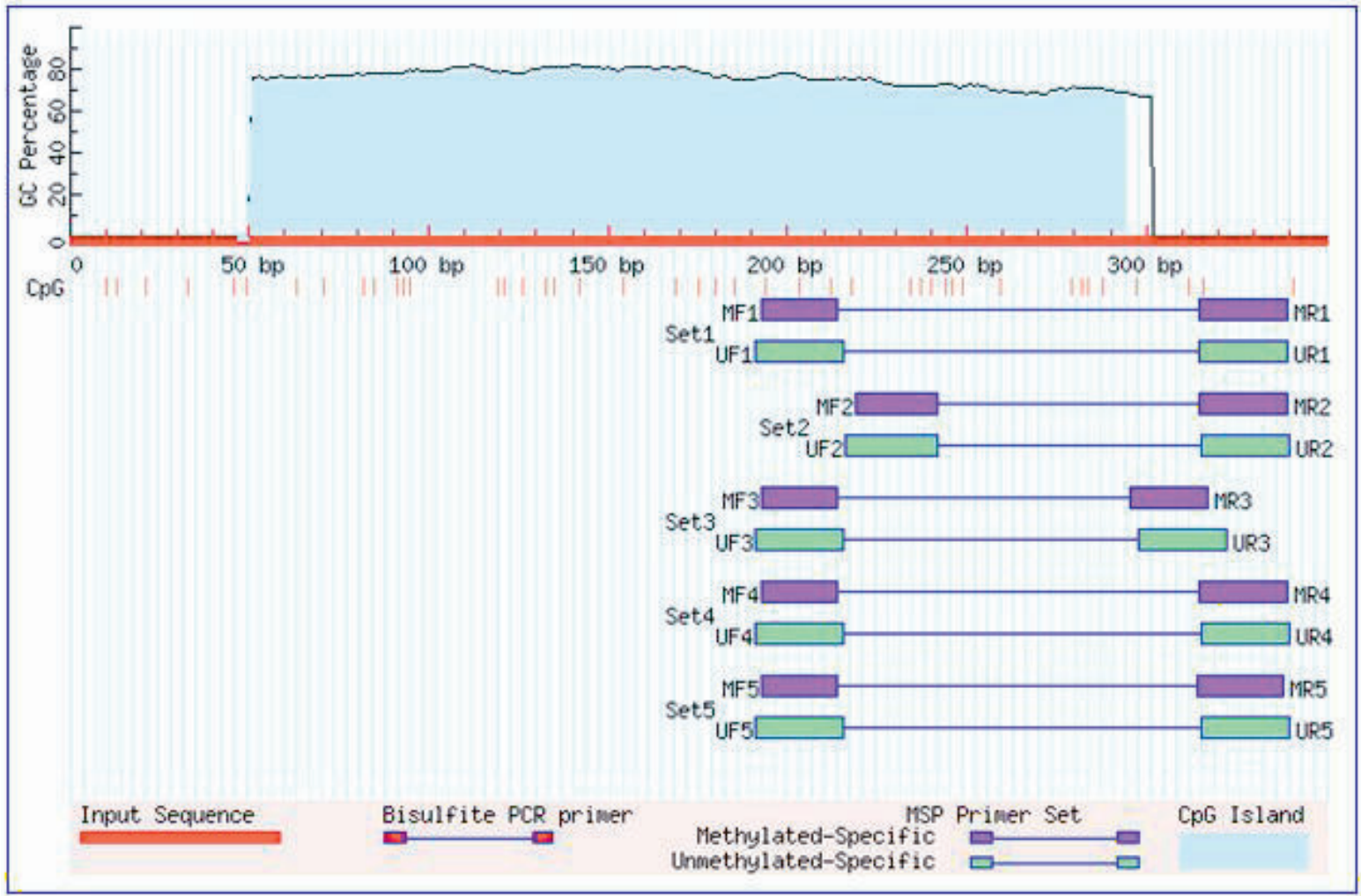

Fig 2. Search result graphic promoters of MSP using MethPrimer.

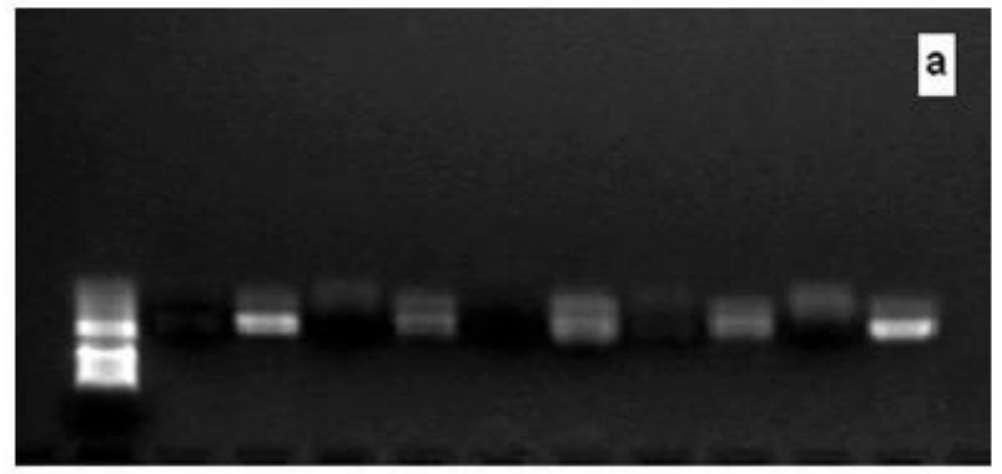

$M \cup M \quad M \quad M \quad M \quad M \quad M \quad M$

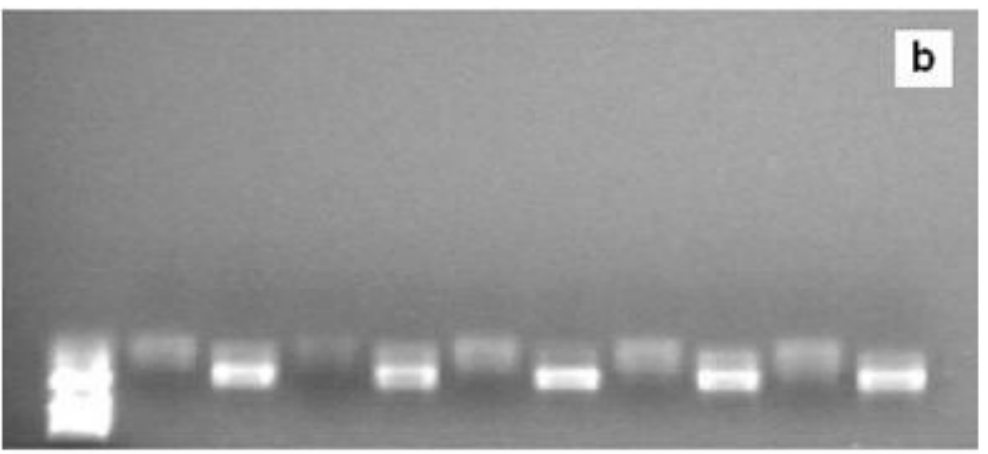

$M \cup M U M U M U M U$

Fig 3. MSP reaction results for $C D K N 2 B$ gene on $6^{\text {th }}$ (a) and $18^{\text {th }}$ (b) day of the embryonic development of Polbar chickens (M - methylated cytosine, $U$ - unmethylated cytosine). 


\section{Results}

The study showed that the $C D K N 2 B$ was not suppressed on the $6^{\text {th }}$ and $18^{\text {th }}$ day of embryonic development of Polbar chickens. The electropherograms present the results of the MSP reaction (Fig. 3). The intensively luminant MSP product bands for which non-methylated primers were used prove that the amplified product did not undergo methylation.

The complete absence of amplification product using primers overlapping the methylated variant of a given segment of DNA (173bp) on the 6th day of development and the presence of a very weak amplification product on the 18th day of embryonic development may provide a small percentage of methylated cytosines in the analyzed DNA fragment at a later stage of embryonic development.

\section{Discussion}

This study aimed at identifying $C D K N 2 B$ methylation during embryonic development in Polbar chickens by means of the MSP (methylationspecific PCR) technique. We hypothesized that the gene $C D K N 2 B$ may be methylated during embryonic development (GRYZIŃSKA et al. 2013).

DNA methylation is a species- and tissuespecific process. It has been shown that the global methylation level rises as a function of the age of both eukaryotic and prokaryotic organisms (RUSSO et al. 1996; BIRD 2002; VANYUSHIN 2005; BOKS et al. 2009; ŁUKASIK et al. 2009). The DNA methylation level may indicate age, and incorrect DNA methylation can lead to premature ageing (LUKASIK et al. 2009). Disorders in DNA methylation control trigger the activation of oncogenes, inactivation of neoplasm suppressor-genes and chromatin stability disorders (VANYUSHIN et al. 2005; ŁUKASIK et al. 2009).

Methylation is also used to control gene expression in embryogenesis (PŁACHETKA et al. 2010). At the beginning of embryonic development, DNA is almost completely devoid of methyl groups (demethylated). Thus, almost all genes are active. Following organogenesis, a large percentage of genes remain suppressed until death (FERGUSON-SMITH \& SURANI 2001; HAKE et al. 2004).

Studies of methylation levels during the embryonic development of chickens revealed a statistically significant increase in DNA methylation between the sixth and eighteenth day (GRYZIŃSKA et al. 2013).

The experiments of the present study revealed that the $C D K N 2 B$ gene is not suppressed on the $6^{\text {th }}$ and $18^{\text {th }}$ day of embryonic development of Polbar chickens, despite a significant rise in global methylation (GRYZIŃSKA et al. 2013). As one of the five genes responsible for the activity of melanin in melanocytes, the highly active $C D K N 2 B$ contributes to the production of this pigment that enables sex differentiation in chicks during the first 24 hours following hatching.

The $C D K N 2 B$ gene in chickens performs a similar function to cyclino-dependent kinase $2 \mathrm{~A}$ $(C D K N 2 A)$ inhibitors analysed for other vertebrate species (KIM et al. 2006). Methylthioadenosine phosphorylase (MTAP) and CDKN2A are associated with malignant melanoma (BORG et al. 2000; BEHRMANN et al. 2003; GOLDSTEIN et al. 2008). However, deletions in these genes have also been identified in other types of neoplastic cells (ISHII et al. 1999; M'SOKA et al. 2000). This shows that these genes may play a more significant role in cell proliferation than previously thought.

A plausible mechanism for the sex-related striped pattern in chickens is that the CDKN2A mutation (or mutations) we identified results in premature cell death, which in turn leads to the formation of white stripes lacking melanocytes. This may be then followed by a new wave of melanocytes recruited from a pool of stem cells, which migrate, colonize the feather follicle, produce melanin and form the next black stripe. Thus, the mutations causing sex-related striation in chickens may have an opposite effect than mutations associated with familiar forms of melanoma in humans (HELLSTRÖM et al. 2010).

Proteins encoded by $C D K N 2 B$ are the functional equivalents of p16INK4a proteins in mammals (CAMPO 1991; DORSHORST \& ASHWELL 2009). INK4A-Arf expression in mice causes melanocytes to age and stimulates the synthesis of the pigment (SVIDERSKAYA et al. 2002).

The CDKN2A gene has also been analysed in reference to the grey colour of the horse coat. The grey coat colour variant in the horse has demonstrated that a cis-acting regulatory mutation in syntaxin 17 (STX17) alters expression of nuclear receptor subfamily 4 , group $\mathrm{A}$, member 3 (NR4A3) and its downstream target cyclin D2 (CCND2) (ROSENGREN PIELBERG et al. 2008). The increased expression of CCND2 is thought to increase the rate of melanocyte proliferation and subsequently deplete the population of melanocyte precursors of the hair prematurely while allowing expansive melanocyte growth in the skin. Over the life span of the horse, this results in greying of the hair since melanoctyes have to undergo cell death as the hair is formed while skin melanocytes durably persist and develop into melanomas. $C D K N 2 B$ may play a similar role in the striation phenotype of the chicken by altering the melanocyte cell cycle in 
a way that prematurely deprives the actively developing regions of the feather follicle of functional melanoctyes. The replenishment of the feather blastema by extrafollicular melanocyte stem cells, if occurring in a regulated and periodic fashion, could explain the alternating areas of feather pigmentation (PIELBERG et al. 2008; DORSHORST \& ASHWELL 2009).

Analyses of DNA methylation in the $C D K N 2 B$ gene in Polbar chickens have provided information on epigenetic mechanisms of autosexing in this species and broadened the general knowledge of the function of epigenetic mechanisms in birds. As one of the locus bar genes, CDKN2B is responsible for melanin activity in melanocytes (CAMPO 1991: DORSHORST \& ASHWELL 2009; HELLSTRÖM et al.2010). The present study not only extends the knowledge of the epigenetic regulation of autosexing in Polbar chickens but can also contribute information on neoplastic transformations in human melanocytes. The experiments presented here indicate that $C D K N 2 B$ expression is not only controlled at the genomic level (mutations) but also at the level of the epigenome (methylation).

Methylation coacts with chromatin modelling, histone deactylation and RNA interference (RNAi). Incorrect DNA methylation is often at the basis of neurological and developmental disorders. Methylation disorders bring about hereditary diseases such as Angelman's syndrome, Prader-Willi syndrome or Beckwith-Wiedeman syndrome, as well as ICF (immunodeficiency, centromeric instability and facial anomaly) syndrome, Rett syndrome and Fragile-X syndrome. DNA methylation is also of crucial importance for neoplastic processes (ROBERTSON \& WOLFE 2000; LAIRD 1997).

In many types of neoplasms, changes in DNA methylation are the most frequently occurring molecular changes (JABŁOŃSKA \& JESIONEK-KUPICKA 2004). These changes most often result in hypomethylation of promotor regions leading to oncogene overexpression and excessive cell proliferation, hypermethylation of promotor regions debilitating suppressor gene functions and hypermethylation causing 5-methylocytosine to deaminate into thymine leading to point mutations in suppressor genes and protooncogenes, as well as the induction of chromosome instability (LAIRD 1997).

\section{References}

AZHIKINA T.L., SvERDLOV E.D. 2005. Study of tissuespecific CpG methylation of DNA in extended genomic loci. Biochemistry (Moscow) 70: 596-603.

BeHRMANN I., WALlNer S., KOMYOD W.,. HeINRICH P.C., SCHUIERER M., BUETTNER R., BOSSERHOFF A.K. 2003.
Characterization of methylthioadenosin phosphorylase (MTAP) expression in malignant melanoma. Am. J. Pathol. 163: 683-690.

BellotT D.W., SKALETSKy H., PyNTIKOVA T., MARDis E.R., GRAVES T., KREMITZKi C., BROWN L.G., ROZEN S., WARREN W.C., WILSON R.K., PAGE D.C. 2010. Convergent evolution of chicken $\mathrm{Z}$ and human $\mathrm{X}$ chromosomes by expansion and gene acquisition, Nature 466: 612-616.

BIRD A. 2002. DNA methylation patterns and epigenetic memory. Genes Dev. 16: 6-21.

BOCKLANDT S., LiN W., SEHL M.E., SANCHEZ F.J., SinSHEIMER J.S., HORVATH S., VILAIN E. 2011. Epigenetic predictor of age. PLOS 6: 1-6.

BOKS M.P., DERKS E.M., WEISENBERGER D.J., STRENGMAN E., JANSON E., SOMMER I.E., KAHN R.S., OPHOFF R.A. 2009. The relationship of DNA methylation with age, gender and genotype in twins and healthy controls. PLOS 18 : 1-8.

BORG A., SANDBERG T., NILSSON K., JOHANNSSON O., KLINKER M., MASBACK A., WESTERDAHL J., OLSSON H., INGVAR C. 2000. High frequency of multiple melanomas and breast and pancreas carcinomas in CDKN2A mutationpositive melanoma families. J. Natl. Cancer Inst. 92: 1260-1266.

CALIK J. 2009. Organizational basis for implementation of poultry genetic resources conservation programmes. Wiad. Zoot. 2: 33-42. (In Polish).

CAMPO J.L. 1991. Use of the sex-linked barring (B) gene for chick sexing on an eumelanotic columbian background. Poult. Sci. 70: 1469-73.

CHUANG J.C., JONES P.A. 2007. Epigenetics and microRNAs. Pediatr. Res. 61: 24-29.

Cleveland D.W., MaO Y., Sullivan K.F. 2003. Centromeres and kinetochores: from epigenetics to mitotic checkpoint signaling. Cell 112: 407-421.

COLLEMAN W.B., RIVENBARK A.G. 2006. Quantitative DNA methylation analysis. J. Mol. Diagn. 8: 152-156.

DAWSON M.A., KOUZARIDES T. 2012. Cancer epigenetics: from mechanism to therapy. Cell 6: 12-27.

DORSHORST B.J., ASHWELL C.M. 2009. Genetic mapping of the sex-linked barring gene in the chicken. Poult. Sci. 88: 1811-1817.

EHRLICH M. 2003. Expression of various genes is controlled by DNA methylation during mammalian development. J. Cell Biochem. 88: 899-910.

FERGUSON-SMITH A.C, SURANI M.A. 2001. Imprinting and the epigenetic asymmetry between parental genomes. Science 10: 1086-1089.

GOLDSTEIN A.M., STACEY S.N., OLAFSSON J.H., JONSSON G.F., Helgason A., Sulem P., Sigurgeirsson B., BeneDIKTSDOTTIR K.R., THORISDOTTIR K., RAGNARSSON R., KJARTANSSON J., KOSTIC J., MASSON G., KRISTJANSSON K., GULCHER J.R., KONG A., THORSTEINSDOTTIR U., RAFNAR T., TUCKER M.A., STEFANSSON K. 2008. CDKN2A mutations and melanoma risk in the Icelandic population. J. Med. Genet. 45: 284-289.

GREGORY T.R. 2002. A bird's-eye view of the C-value enigma: genome size, cell size, and metabolic rate in the class aves. Int. J. Org. Evolution 56: 121-130.

GRUBER B.M. 2011. Epigenetics and etiology of neurodegenerative diseases. Postepy Hig. Med. Dosw. 65: 542-551. (In Polish with English summary).

GRYZIŃSKA M., NIESPODZIEWAŃSKI M. 2009. History of the autosexing breed of polbar $(\mathrm{Pb})$ hens. Wiad. Zootech. 1: 31-35. (In Polish with English summary).

GRYZIŃSKA M., NIESPODZIEWAŃSKI M., WIDOMSKI P. 2008a. Influence of age on morphometric characteristics of the male reproductive tract of Polbar breed chickens, Medycyna Wet. 64: 344-347. 
GRYZIŃSKA M. NIESPODZIEWAŃSKI M., WIDOMSKI P. $2008 \mathrm{~b}$. Influence of age on morphometric features of the female reproductive tract of polbar hens. Medycyna Wet. 64 489-492.

GRYZIŃSKA M., ANDRASZEK K., STRACHECKA A., JOCEK G. 2012. Effect of DNA methylation on carcinogenesis. Przegląd Hodowlany 3/4: 1-3. (In Polish).

GRYZIŃSKA M., BŁASZCZAK E., STRACHECKA A., JEŻEWSKA-WITKOWSKA G. 2013. Analysis of age-related global DNA methylation in chicken. Biochem. Genet. 51, (DOI 10.1007/s10528-013-9586-9) (in press).

HAKE S.B., XIAO A., ALLIS C.D. 2004. Linking the epigenetic 'language' of covalent histonemodifications to cancer. Br. J. Cancer 90: 761-769.

HellStröM A.R., SUnDSTRÖM E., GUNNARSSON U., BED'HOM B., TIXIER-BOICHARD M., HONAKER C.F., SAHLQVist A.S., JENSEN P., KÄMPE O., SIEGEL P.B., KER.JE S., ANDERSSON L. 2010. Sex-linked barring in chickens is controlled by the CDKN2A / B tumour suppressor locus. Pigment Cell Melanoma Res. 23: 521-530.

Herman J.G., GrafF J.R., MYOHanen S., NELKin B.D., BA YLIN S.B. 1996. Methylation-specific PCR: A novel PCR assay for methylation status of $\mathrm{CpG}$ islands. PNAS $\mathbf{9 3}$ : $9821-9826$

ICGSC 2004. Sequence and Comparative Analysis of the Chicken Genome Provide Unique Perspectives on Vertebrate Evolution. Nature 432: 695-716.

ISHII N., MAIER D., MERLO A., TADA M., SAWAMURA Y., DISERENS A.C., VAN MEIR E.G. 1999. Frequent coalterations of TP53, p16/CDKN2A, p14ARF, PTEN tumor suppressor genes in human glioma cell lines. Brain Pathol. 9 469-479.

JABŁOŃSKA J., JESIONEK-KUPICKA D. 2004. Epigenetic changes in cancers. Onkologia Polska 4: 181-185. (In Polish with English summary).

JONES P.A., MARTIENSSEN R. 2005. A blueprint for a human epigenome project: The AACR Human Genome Workshop. Cancer Res. 65: 11241-11246.

KAUFMAN L. 1963. Polbar a New autosexing breed. Roczniki Nauk Rolniczych 3: 361-374. (In Polish with English summary).

KIM S. H., ROWE J., FUJII H., JONES R., SCHMIERER B., KONG B. W., KUCHLER K., FOSTER D., ISH-HOROWICZ D., PETERS G. 2006. Upregulation of chicken p15INK4b at senescence and in the developing brain. J. Cell Sci. 119: 2435-2443.

LAIRD P. W. 1997. Oncogenic mechanisms mediated by DNA methylation. Mol. Med. Today 3: 223-229.

LiMA P.S., MOLFFETA G.A., GÓES DE ARAUJO A. , ZAGO M.A., ARAÚJO DA SILVA W. 2008. DNA methylation analysis of the tumor suppressor gene $C D K N 2 B$ in Brazilian leukemia patients. Gen. and Mol. Biol. 31: 632-638

LUKASIK M., KROCHMALSKA J., SZUTKOWSKI M. M., ŁUKASZEWICZ J. 2009. Effect of DNA methylation on genome function. Biul. Wydz. Farm. WUM 2: 13-18. (In Polish with English summary).
MASABANDA J.S., BURT D.W. O'BRIEN P.C., VignAL A., FILLON V., WALSH P.S., COX H., TEMPEST H.G., SMITH J., HABERMANN F., SCHMid M., MATSUdA Y., FERGUSON-SMITH M. A., CROOIJMANS R.P., GROENEN M.A., GRIFFIN D.K. 2004. Molecular Cytogenetic Definition of the Chicken Genome: The First Complete Avian Karyotype. Genetics 166: 1367-1373.

M'SOKA T.J., NiSHIOKA J., TAGA A., KATO K., KAWASAKI H., YAMADA Y., YU A., KOMADA Y., NOBORI T. 2000. Detection of methylthioadenosine phosphorylase (MTAP) and p16 gene deletion in T cell acute lymphoblastic leukemia by real-time quantitative PCR assay. Leukemia 14: 935-940.

OLSZEWSKA M. 2007. Heterochromatin and "heterochromatinization". Post. Biol. Kom. 34: 391-407. (In Polish).

PŁACHETKA A., WiCZKOWSKi A., ZALEWSKA-ZioB M., WILCZEK G., MUC-WIERZGOŃ M., KOKOT T., NOWAKOWSKA-ZAJDEL E. 2010. The role of epigenetic changes in tumor formation. Wydawnictwo Slaskiego Uniwersytetu Medycznego. Katowice. 4-50. (In Polish).

REIK W., DEAN W., WALTER J. 2001. Epigenetic reprogramming in mammalian development. Science 293: 1089-1093.

ROBERTSON K. D., WOLFFE A. P. 2000. DNA methylation in health and disease. Nat. Rev. Genet. 1: 11-19.

Rosengren Pielberg G., Golovko A., Sundstrom E., CURIK I., LENNARTSSON J., SELTENHAMMER M.H., DRUML T., BINNS M., FITZSIMMONS C., LINDGREN G., SANDBERG K. BAUMUNG R. VETTERLEIN M., STROMBERG S., GRABHERR M., WADE C., LindBLAD-TOH K., PONTEN F., Heldin C.H., SOlKNer J., ANDERSSON L. 2008. A cis-acting regulatory mutation causes premature hair graying and susceptibility to melanoma in the horse. Nat. Genet. 40: 1004-1009.

RUBIN C.J., ZODY M.C., ERIKSSON J., MEADOWS J.R., SHERWOOD E. WEBSTER M.T. JIANG L. INGMAN M., SHARPE T., Ka S., HallböÖK F., Besnier F., Carlborg O., BED'HOM B., TiXIER-BOICHARD M., JENSEN P., SiEGEL P., LINDBLAD-TOH K., ANDERSSON L. 2010. Whole-genome resequencing reveals loci under selection during chicken domestication. Nature 464: 587-591.

Russo V.E.A., MARTIENSSEN R.A., RIGGS A.D. 1996. Epigenetic Mechanisms of Gene Regulation. Cold Spring Harbor Laboratory Press. Woodbury. 1-4.

Sulewska A., NiKlińsKa W., KOZŁoWSKi M., MinAROWSKI Ł., NIKLIŃSKI J., DABROWSKA K., CHYCZEWSKI L. 2007. Detection of DNA methylation in eukaryotic cells. Folia Histochem. Cytobiol. 45: 315-324.

SVIDERSKAYA E.V., HILl S.P., EVANS-WHIPP T.J., CHIN L., ORLOW S.J., EASTY D.J., CHEONG S.C., BEACH D., DEPINHO R.A. BENNET D.C. 2002. p16(Ink4a) in melanocyte senescence and differentiation. J. Natl. Cancer Inst. 94: 446-454.

VANYUSHIN B.F. 2005. Enzymatic DNA methylation is an epigenetic control for genetic functions of the cell. Biochemistry 70: 488-499.

WÓJCIK E., ANDRASZEK K., GRYZIŃSKA M., WITKOWSKI A., PAŁYSZKA M., SMALEC E. 2012. Sister chromatid exchange in Greenleg Partridge and Polbar hens covered by the genepool protection program for farm animals in Poland. Poult. Sci. 91: 2424-2430. 